Document downloaded from:

http://hdl.handle.net/10251/98938

This paper must be cited as:

Serrano Lanzarote, AB.; Ortega Madrigal, L.; Garcia-Prieto Ruiz, A.; Soto-Francés, L.; Soto Francés, VM. (2016). Strategy for the energy renovation of the housing stock in Comunitat Valenciana (Spain). Energy and Buildings. 132:117-129. doi:10.1016/j.enbuild.2016.06.087

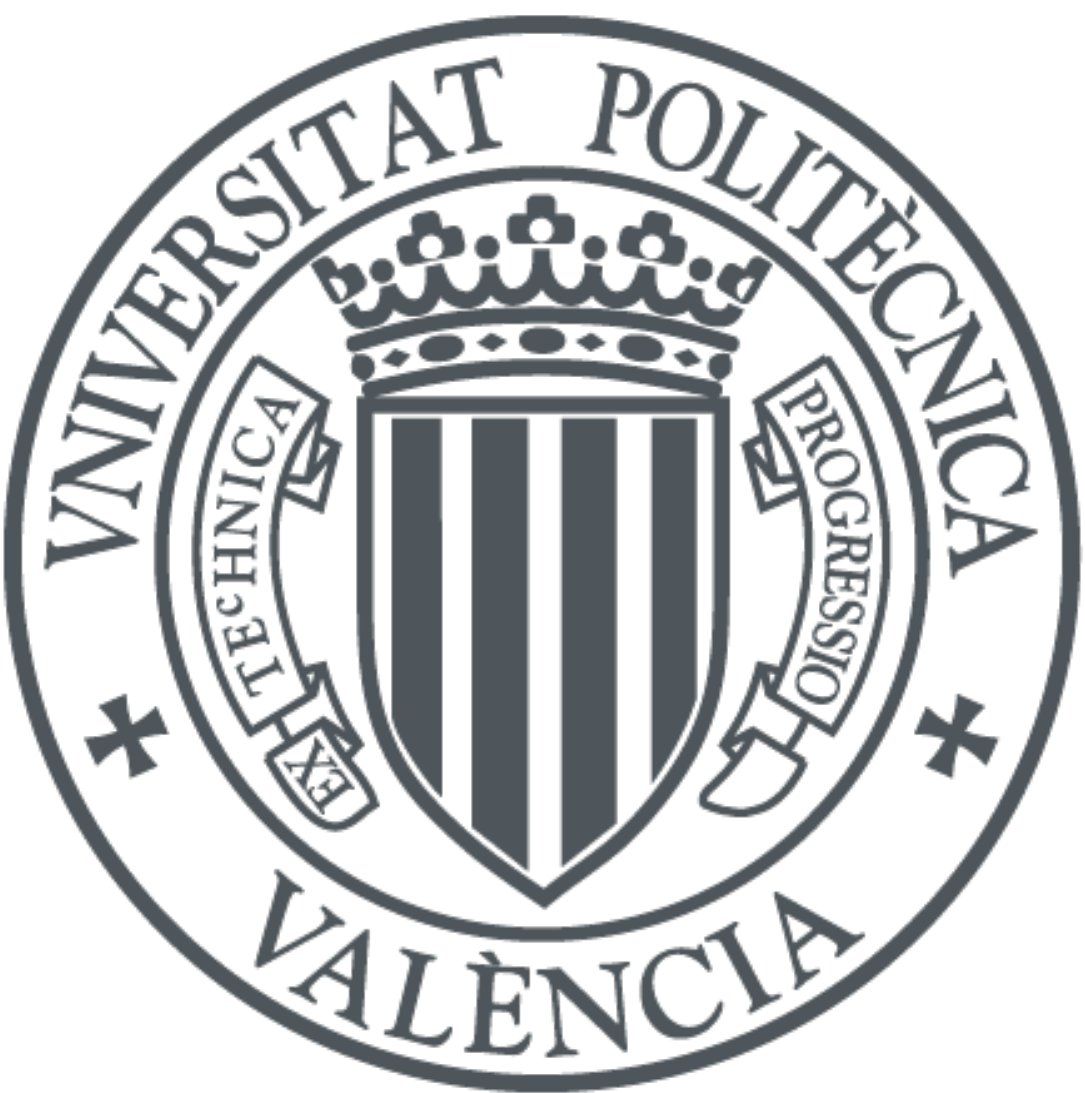

The final publication is available at

https://doi.org/10.1016/j.enbuild.2016.06.087

Copyright Elsevier

Additional Information 


\title{
Strategy for the energy renovation of the housing stock in Comunitat Valenciana (Spain).
}

\author{
Begoña Serrano-Lanzarote ${ }^{a, *}$, Leticia Ortega-Madrigal ${ }^{\mathrm{a}}$, Alejandra García-Prieto-Ruiz ${ }^{\mathrm{a}}$, Laura \\ Soto-Francés $^{\mathrm{a}}$, Victor-Manuel Soto-Francés ${ }^{\mathrm{b}}$ \\ ${ }^{a}$ Instituto Valenciano de la Edificación, Valencia (IVE).C/ Tres forques 98. 46018 Valencia (Spain) \\ ${ }^{b}$ Departamento de Termodinámica Aplicada. ETSII. Universitat Politècnica de Valencia. C/ Camino de vera \\ s/n. 46022 Valencia (Spain)
}

\begin{abstract}
The Spanish residential building stock built between 1940-1980 period presents a high energy saving potential as it represents a significant percentage of the total housing stock and it was built without any regulation regarding energy efficiency. Accordingly, the first aim of this paper was to quantify the energy saving potential and the related reduction in $\mathrm{CO}_{2}$ emissions of the housing stock in those years. The work focuses on the Mediterranean climate of the Comunitat Valenciana Region, therefore the energy efficiency strategies proposed are passive and deal with the envelope of buildings. On the basis of the results obtained, several scenarios with intervention periods of 10, 20 and 30 years were calculated. The conclusion was that with the current rate of annual building renovation, it will be nearly impossible to reach the goals established by the EPBD. Only a deep transformation of the building fabric within this sector could help in achieving them. Finally, it should be noted that the proposed methodology can be applied to other areas with different climates, particularly in Spain.
\end{abstract}

Keywords: energy retrofitting, energy efficiency, $\mathrm{CO}_{2}$ emissions reduction, improvement scenarios, energy saving potential, energy action plan

\section{Introduction}

Nowadays everybody agrees about the importance of the environmental, social and economic benefits reached through the renovation of the housing building stock, including energy retrofitting in a significant way.

\footnotetext{
* Corresponding author

Email addresses: bserranol@five.es (Begoña Serrano-Lanzarote), lortega@five.es ( Leticia Ortega-Madrigal), sgarciap@five.es (Alejandra García-Prieto-Ruiz), Isoto@five.es (Laura Soto-Francés), vsoto@ter.upv.es ( Victor-Manuel Soto-Francés )
} 
The new Energy Performance in Buildings Directive (EPBD) [1] requires a $20 \%$ reduction in the emissions of warming effect gases, a $20 \%$ reduction in energy consumption and a $20 \%$ increase in the use of renewable energy (known as Horizon 20/20/20). These goals cannot be achieved just by acting on new buildings. In conclusion, there is a need to energy retrofit the existing housing stock in order to meet the Horizon 20/20/20 targets.

In this framework, there is a significant potential for promoting energy conservation in existing residential buildings in Spain, as most of the building stock were constructed before the introduction of the first Building Regulation for Thermal Insulation in 1979. These buildings are, by and large, lacking adequate thermal insulation and they are primary candidates for a large scale energy renovation programme.

However, in order to enhance the effectiveness of such programmes, both in terms of economics and energy efficiency, a deeper knowledge of the features about the building stock is needed, as well as to ensure the most suitable and efficient energy saving measures. Moreover, an evaluation of the feasibility of different measures and a considered elaboration of financing and marketing tools are also needed in order to address building owners, who have already been stretched by the recession.

Thus far, the research in Spain regarding building stock analysis and the devising of a roadmap has been developed only at national level by GTR [2]. GTR's report provides the background and the framework methodology needed for structuring an Action Plan for the housing sector. This report was used as a base for the development of the National Roadmap Plan required by the EPDB [ $D$ However, prior to this study, there were none at regional level taking into account the large differences among regions. In fact, one of the main conclusions of the GTR was that there is a need for developing studies at regional level. The investigation here presented is being used as a reference for the other Spanish regions in a working group created specially for developing regional studies.

The opportunity to refurbish and upgrade Valencia's residential buildings is sizeable, economically feasible and it can go a long way towards reforming and refocusing the Valencia Region's building sector, which is badly impacted by the financial crisis and is currently failing to meet the environmental challenges presented by the Global Climate Change.

\section{Objectives}

In this framework, the main objective of this paper is to set the possible intervention scenarios out, based on the building stock segmentation and on the actual energy consumption data. The 
scenarios are defined by the variation of the factors that determine the scope of the consumption reduction over time. The improvement possibilities and the investment costs to reduce the energy consumption, for each of the building types, has been taken into account. This implies that the investment must be cost effective or at least assure future energy cost savings.

Hence, this paper provides the background, framework and methodology to structure an Action Plan for the Energy Efficiency refurbishment of the Residential Building Stock at the Comunitat Valenciana. The results will guide the development of a solid and supportive policy consisting of facilitating legislation, direct subsidies, low cost finance and fiscal benefits to refurbishment.

\section{Scope}

To reach the main objective it was necessary to characterize the existing housing stock in Comunitat Valenciana as it is described below and to evaluate its potential energy savings, along with the potential reduction in $\mathrm{CO}_{2}$ emissions.

It is worth noting that the information about the age of the housing stock, its urban distribution, its typological characteristics and its state of conservation, is essential to identify and prioritize the most effective and efficient energy saving measures.

As for the characterization of the existing housing stock, a thorough investigation was carried out, based on state of the art data collection procedures as the ones used in previous European projects DATAMINE [3], TABULA [4] and REPUBLICZEB [5], so as to determine a basic classification of buildings, according to their typology and date of construction. This classification resulted from the analysis of statistical data from a national research project [6] and the Spanish National Statistics Institute (INE data base [7]). The INE database is available to researchers in electronic form at the INE website [7].

As a result of the analysis of the statistical data, the scope of this research was focused on multifamily houses at the Comunitat Valenciana Region (Spain) which were constructed between 1940 and 1980. This set of buildings represents the $60 \%$ of the total dwelling stock. According to INE, there are 55,601 residential buildings among those constructed between 1940 and 1980 in Comunitat Valenciana, which contain 692,641 primary residences. These buildings were built before the enactment of the first Spanish law (NBE-CT-79) demanding the inclusion of thermal insulation in buildings. It was published in the late 1970s but, unfortunately, it took some time to propagate through the whole building sector. Furthermore, this stock, which is between thirty five and seventy five-year old, has also had a low investment in conservation and maintenance 
to date. Thus, this segment has a special significance within the housing stock as it provides interesting possibilities for upgrading and it has also the greatest energy saving opportunities.

\section{Methodology}

The work of this study was undertaken to address an urgent need to describe the residential building stock at Valencia, in order to allow the assessment of the effects of different energy saving measures. A top-down approach was used by splitting the actual energy consumption of the regional building stock among the total number of buildings. Surprisingly, large differences showed up when comparing this actual energy consumption to the theoretical one obtained from the Spanish Energy Certification of Buildings scheme. On the contrary, other researchers have applied a bottom-up approach for replicating the building stock energy performance, which consists in clustering and aggregating the buildings at city scale. Afterwards, building stock is segmented into archetype buildings and the energy demand and consumption of the stock is computed [8]. However, in our opinion, bottom-up approaches have the disadvantage of being based on a theoretical energy consumption. This is an important drawback when trying to estimate the absolute value of the actual savings.

A top-down approach can be split into three steps:

1. The segmentation of the building stock, or in other words, to decide the required number of archetypes to represent the entire stock.

2. The characterization of these archetypical buildings according to some previously selected parameters. The TABULA methodology [4] has been applied to characterize the housing stock through a number of archetypical buildings. An archetypical building is a selected building which represents a whole class of buildings which share the same characteristics. In concrete, four types of multifamily buildings have been identified based on data from the RehEnerga project [6] and INE [9]. Their characteristics have also been obtained from previous projects and National reports (see for more details [10] [11] [9]).

The age of buildings has not been used as a parameter as the building stock analysed was built from 1940 to 1980 and the morphology of the residential buildings remained quite similar during this period [10].

3. The quantification of the archetypes consists in finding how many buildings are represented by each archetype within the building stock. In this case, the climatic zones have also been taken into account. Table 5 shows the results. 
After the building stock is described by archetypical buildings, an energy simulation of each archetype was conducted using the dynamic simulation tool CERMA [12], which fulfils the National Building Energy Certification requirements [13]. CERMA is a single thermal zone simulation engine. Its calculation method is dynamical,i.e., based on conduction heat transfer functions, with a time step of one hour. It features an in-built parametric tool for studying improvements in the architecture and in the HVAC facilities. The simulation outputs included the net energy demand and the final energy consumption of each building type. Accordingly the energy demand of the entire building stock under investigation, was obtained as well. Next, the overall energy demand was classified according to the climatic zones of the Valencia Region.

In order to calibrate the categorization and the outputs of the energy simulation with respect to the computed values, more accurate values were sought about the actual energy consumption in the statistical local records from the Regional Government of Valencia [14].

Once the model was calibrated by building types and per climatic zone, energy saving measures were proposed for the improvement of the envelope of the buildings.

An innovative approach was introduced for the selection of the energy saving measures. It is a threefold criteria evaluation method regarding; comfort, energy and economics. The idea was to obtain enough technical and economic information about a set of passive energy saving measures, in order to take the right decisions. The economic calculation was based on the global costs, which considers the running costs and the investment costs over a long period. The outputs from the evaluation of the selected measures and their combination are:

1. Number of annual dwellings renovated.

2. Energy and $\mathrm{CO}_{2}$ emissions saved by renovations.

3. Public and private investment required.

As a result of the evaluation, from a set of a priori potentially good measures, a small subset of them was selected for each type of building. Multiple combinations of them were calculated in order to find the more feasible scenarios. Finally, the energy savings resulting from implementing these measures was estimated. The outputs from the simulation were given in an aggregated form for the studied building stock. At the end a proposal for an Action Plan for the Valencia Region was devised, by establishing several intervention scenarios throughout a 10-year period (20122021). The plan was designed from a realistic point of view, both technically and economically.

In short, this section shows that the model employed to make decisions is generated by a topdown approach. Thus, the modelling assumes that a small mount of archetypical buildings can 
be used as representatives of the region to be evaluated. The energy demand and associated $\mathrm{CO}_{2}$ emissions of the existing stock were obtained for a reference (or baseline) year. The potential of improvements can be assessed and compared to this reference.

In what follows, the usefulness of the model is demonstrated by the energy assessment of the building archetypes and the selection of the best energy saving measures.

\section{Evaluation of the energy demand.}

As explained above, in order to plan and promote the respective energy renovation scenarios, a thorough analysis of the building stock under study was carried out. Table 1 is based on the Spanish National Institute of Statistics (INE) database. It shows how the most relevant groups of buildings are multifamily houses built between 1960 and 1980. It is worth to point out that the knowledge of the distribution of the housing stock allows the establishment of specific intervention strategies which guarantee a much more optimised assignment of the resources and effectiveness of the actions.

\subsection{Climatic zones.}

As shown in Table 2, the distribution of the municipalities among the climatic zones according to the Spanish Building Code CTE [15] was studied. The limit of the energy demand fixed by the CTE depends on the climatic zone where the building is located. It should be remarked that the improvement measures proposed in this study were oriented towards the fulfilment of the CTE as discussed hereinafter. Therefore the information contained in Table 2 is relevant to select the most appropriate improvement measures.

The CTE divides Spain into 12 climatic zones. The climatic zones are identified by a letter corresponding to the severity of winter (A, B, C, D, E), ranked by increasing severity, (E is the coldest) and by a number corresponding to the severity of summer $(1,2,3,4)$, ranked also by increasing severity ( 4 is the hottest). The climatic severity index combines several indexes like the degree-days or the solar radiation. Therefore, when two locations have the same winter severity, the expected heating energy demand of the same building placed in both should be lower than a given reference value fixed by the CTE. The same applies for the summer severity and the cooling energy demand. By combining the five winter possibilities with the four summer possibilities, 20 different areas are potentially possible, however only 12 actually exist in Spain.

The distribution of multifamily houses among the municipalities was also examined with the goal of distinguishing the measures to be implemented in each climatic zone. As it is illustrated 
in Table 2, $84 \%$ of the multifamily houses are located in areas with low winter severity and high summer severity.

\subsection{Typological and technical characterization of buildings.}

According to the methodology aforementioned, four building types were established to represent the building stock analysed. Table 3 presents the distribution of dwellings by type (see [6]). Table 4 displays the types and their original construction characteristics (see [10], [6]). Strangely enough, the actual construction characteristics of the buildings of the Comunitat Valenciana Region do not depend on the climatic zone.

Table 5 contains the details of the quantity of buildings per climatic zone classified by their typology and floor area. It should be notice that types 1 and 2 gather more than $95 \%$ of the floor area.

Finally, Table 6 shows the thermal facilities proposed for the original state of the buildings.

\subsection{Computation of the HVAC energy demand by typology and climatic zone.}

The computation of the heating and cooling energy demands of the building types proposed was done using the CERMA software [12]. The model definition is non-geometrical to avoid 3D modelling although it takes into account shadings. Due to the fact that CERMA is an officially recognized tool for energy certification of buildings in Spain, the profiles of occupancy, lighting and the comfort temperature set-points are enforced by the Spanish regulation established by law [13] and cannot be modified.

The outcomes from CERMA were compared afterwards with the actual energy consumption data coming from the housing sector database [14]. The comparison of the heating season leads to the conclusion that there is a certain percentage of the computed energy demand that is not covered by the actual facilities and the same applies for cooling. There may be various reasons for this. Our opinion is that the systems might not follow the same use patterns than the ones forced by law in the calculation programs: for instance, the HVAC systems availability periods are different (in other words, people use less hours the heating/cooling equipment than assumed by law), different temperature set-points, etcetera.

Table 7 summarizes the comparison for heating. It shows the computed heating energy demand and the energy demand actually covered by the systems per square meter of air-conditioned area. The mean floor area of a dwelling in the Valencia Region is $85 m^{2}$ [9]. Table 7 also shows that variations are larger in warm areas (less severe winter) than in colder climates. 


\begin{tabular}{cccc}
\hline Year of construction & Floors & Single family & multifamily houses \\
\hline \multirow{2}{*}{$\leq 1960$} & $<4$ & 292,935 & 325,155 \\
& $\geq 4$ & 97 & 200,237 \\
\hline \multirow{2}{*}{$1961-1980$} & $<4$ & 200,997 & 648,751 \\
& $\geq 4$ & 189 & 515,107 \\
\hline \multirow{2}{*}{$\geq 1980$} & $<4$ & 252,436 & 325,456 \\
& $\geq 4$ & 444 & 209,156 \\
\hline
\end{tabular}

Table 1: Distribution of dwellings by year of construction, number of floors and type of building (Comunitat Valenciana (Spain), according to the Final report Rehenergia project [6] and the Spanish National Statistics Institute (INE) [7].

\begin{tabular}{ccccc}
\hline Climatic zone & Winter severity & Summer severity & Municipalities(\%) & multifamily houses (\%) \\
\hline B3 & Low & High & 38 & 57 \\
B4 & Low & High & 11 & 27 \\
C1 & Medium & Low & 12 & 5 \\
C2 & Medium & Medium & 16 & 2 \\
C3 & Medium & High & 5 & 4 \\
D1 & High & Low & 16 & 3 \\
E1 & High & Low & 2 & 0 \\
\hline
\end{tabular}

Table 2: Distribution of municipalities and multifamily houses among the climatic zones of the Comunitat Valenciana(Spain), according to Valencia Regional Energy Agency (AVEN) [14]. 


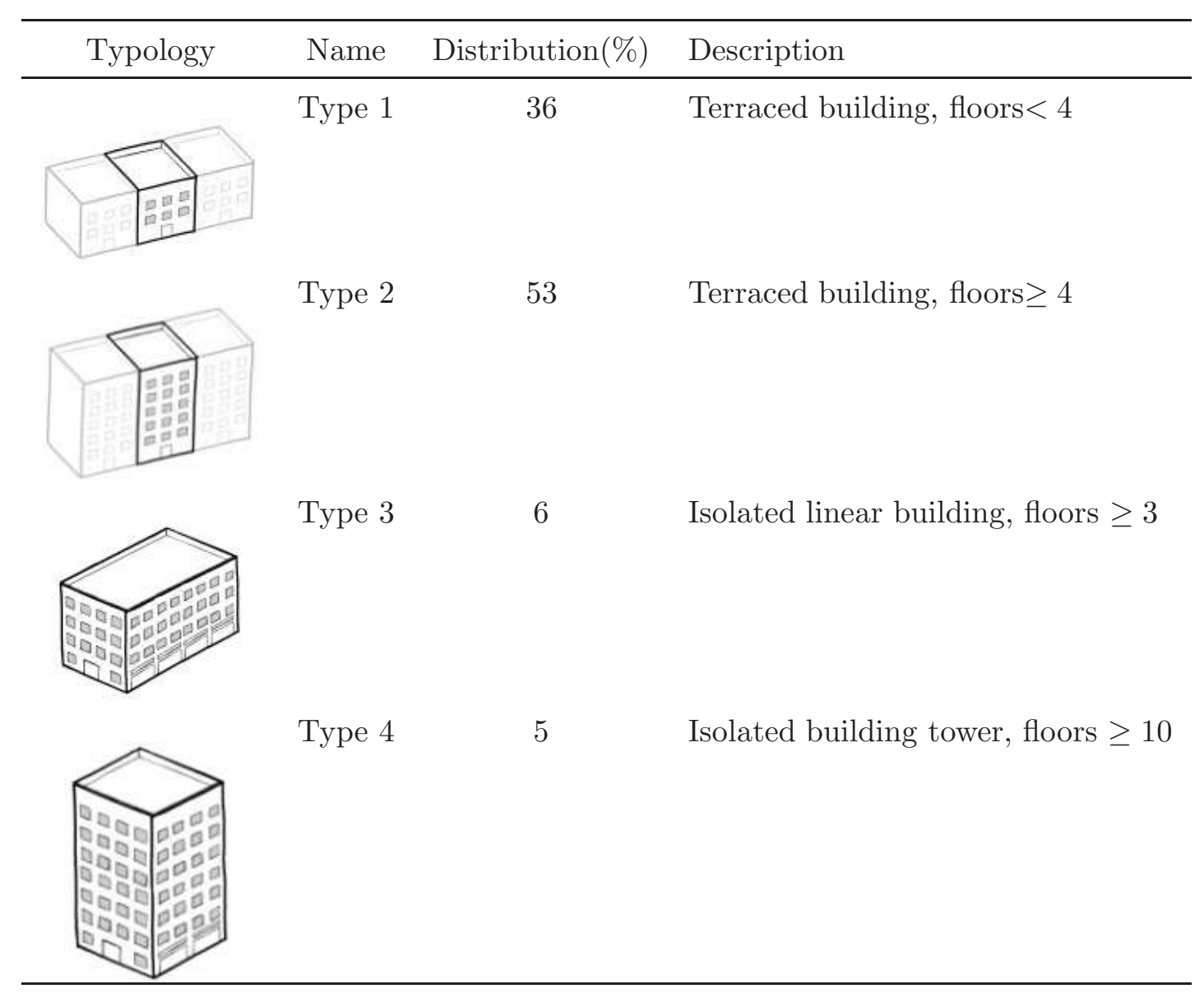

Table 3: Proposed housing typologies and their distribution in the Comunitat Valenciana (Spain), according to statistical data.(Source: own elaboration). 


\begin{tabular}{|c|c|c|c|c|}
\hline & Type $1 \&$ Type 2 & & Type 3 \& Type 4 & \\
\hline & \multicolumn{4}{|c|}{ CONSTRUCTION CHARACTERISTICS (INITIAL STATE) } \\
\hline Element & & $\mathrm{U}\left(W m^{-1} K^{-1}\right)$ & Description & $\mathrm{U}\left(W m^{-1} K^{-1}\right)$ \\
\hline Main facade & $\begin{array}{l}\text { Concrete mortar } \\
\text { Void brick } 115 \mathrm{~mm} \\
\text { Airgap } 30 \mathrm{~mm} \\
\text { Void brick } 40 \mathrm{~mm} \\
\text { Gypsum mortar }\end{array}$ & 1.39 & $\begin{array}{l}\text { Perforated brick } 115 \mathrm{~mm} \\
\text { Air gap } 30 \mathrm{~mm} \\
\text { Void brick } 40 \mathrm{~mm} \\
\text { Gypsum mortar }\end{array}$ & 1.43 \\
\hline Interior facade & $\begin{array}{l}\text { Concrete mortar } \\
\text { Void brick } 70 \mathrm{~mm} \\
\text { Gypsum mortar }\end{array}$ & 2.63 & $\begin{array}{l}\text { Concrete mortar } \\
\text { Void brick } 115 \mathrm{~mm} \\
\text { Gypsum mortar }\end{array}$ & 2.08 \\
\hline Internal partitions & $\begin{array}{l}\text { Gypsum mortar } \\
\text { Void brick 70mm } \\
\text { Gypsum mortar }\end{array}$ & 2.00 & $\begin{array}{l}\text { Gypsum mortar } \\
\text { Void brick 70mm } \\
\text { Gypsum mortar }\end{array}$ & 2.00 \\
\hline Roofs & $\begin{array}{l}\text { Ceramic tile } \\
\text { Grip mortar } \\
\text { Waterproof barrier } \\
\text { Concrete } \\
\text { Unidirectional slab reinforced concrete } \\
\text { Gypsum mortar }\end{array}$ & 1.92 & $\begin{array}{l}\text { Ceramic tile } \\
\text { Grip mortar } \\
\text { Waterproof barrier } \\
\text { Concrete } \\
\text { Unidirectional slab reinforced concrete } \\
\text { Gypsum mortar }\end{array}$ & 1.92 \\
\hline Slabs & $\begin{array}{l}\text { Terrazzo tile } \\
\text { Grip mortar } \\
\text { Unidirectional slab reinforced concrete } \\
\text { Gypsum mortar }\end{array}$ & 1.72 & $\begin{array}{l}\text { Terrazzo tile } \\
\text { Grip mortar } \\
\text { Unidirectional slab reinforced concrete } \\
\text { Gypsum mortar }\end{array}$ & 1.72 \\
\hline Frames/Joinery & $\begin{array}{l}\text { Metallic joinery } \\
\text { Hinged } \\
\text { Bad fitting } \\
\text { Blinds-box without insulation, } 0.4 \mathrm{~mm} \text { air gap }\end{array}$ & 5.70 & $\begin{array}{l}\text { Metallic joinery } \\
\text { Hinged } \\
\text { Bad fitting } \\
\text { Blinds-box without insulation, } 0.4 \mathrm{~mm} \text { air gap }\end{array}$ & 5.70 \\
\hline
\end{tabular}

Table 4: Constructive characteristics for the envelope of buildings types $1,2,3 \& 4$, according to the catalogue for constructive elements for retrofitting.(Source [10]). 


\begin{tabular}{|c|c|c|c|}
\hline $\begin{array}{l}\text { Type } \\
\text { of building }\end{array}$ & $\begin{array}{l}\text { Climatic } \\
\text { zone }\end{array}$ & $\begin{array}{l}\text { Number } \\
\text { of dwellings }\end{array}$ & $\begin{array}{l}\text { Multifamily } \\
\text { housing area }\left(m^{2}\right)\end{array}$ \\
\hline \multirow{7}{*}{ Type 1} & B3 & 160,796 & $11,818,506$ \\
\hline & $\mathrm{B} 4$ & 45,574 & $3,496,689$ \\
\hline & $\mathrm{C} 1$ & 8,189 & 601,892 \\
\hline & $\mathrm{C} 2$ & 10,294 & 802,914 \\
\hline & $\mathrm{C} 3$ & 13,582 & 998,277 \\
\hline & D1 & 7,227 & 531,185 \\
\hline & E1 & 53 & 3,896 \\
\hline \multirow{7}{*}{ Type 2} & B3 & 220,383 & $20,826,194$ \\
\hline & B4 & 91,535 & $8,650,058$ \\
\hline & $\mathrm{C} 1$ & 27,011 & $2,552,540$ \\
\hline & $\mathrm{C} 2$ & 2,715 & 256,568 \\
\hline & $\mathrm{C} 3$ & 15,078 & $1,424,871$ \\
\hline & D1 & 10,115 & 955,868 \\
\hline & E1 & 53 & 5,009 \\
\hline \multirow{7}{*}{ Type 3} & B3 & 13,698 & 958,860 \\
\hline & B4 & 23,796 & $1,665,720$ \\
\hline & $\mathrm{C} 1$ & 0 & 0 \\
\hline & $\mathrm{C} 2$ & 114 & 7,980 \\
\hline & $\mathrm{C} 3$ & 555 & 38,850 \\
\hline & D1 & 522 & 36,540 \\
\hline & E1 & 0 & 0 \\
\hline \multirow{7}{*}{ Type 4} & B3 & 13,716 & $1,152,144$ \\
\hline & B4 & 23,802 & $1,999,368$ \\
\hline & $\mathrm{C} 1$ & 0 & 0 \\
\hline & $\mathrm{C} 2$ & 114 & 9,576 \\
\hline & C3 & 561 & 47,124 \\
\hline & D1 & 528 & 44,352 \\
\hline & E1 & 0 & 0 \\
\hline
\end{tabular}

Table 5: Distribution during the period 1940-1980, according to statistical data analysis . (Source: own elaboration). 


\begin{tabular}{ll}
\hline Facility & Initial state \\
\hline \multirow{2}{*}{ Domestic Hot Water (DHW) } & Gas water heater \\
& Nominal heating power $24 \mathrm{~kW}$ \\
& Nominal efficiency $80 \%$. No storage \\
\hline \multirow{3}{*}{ Heating } & Electric heater \\
& Nominal heating power $1 \mathrm{~kW}$ per terminal \\
& 4 heaters per dwelling \\
\hline Cooling & Compression cooling machine \\
& Seasonal Energy Efficiency Ratio SEER 1.70 \\
\hline Equipment/Fuel type & Seasonal efficiency according to the Catalogue of constructive elements for retrofitting \\
\hline Boiler / Gas-oil & 0.75 \\
Boiler / Liquified gas & 0.80 \\
Boiler / Natural gas & 0.85 \\
Electric heater / Electricity & 1.00 \\
Domestic heat pump/Electricity & SCOP=1.90, SEER=1.75 \\
\hline
\end{tabular}

Table 6: Technical facilities characteristics according to the catalogue of constructive elements for retrofitting [10].(Source: own elaboration). 


\begin{tabular}{lrrrrrrr}
\hline Building Type & \multicolumn{7}{c}{ Computed heating energy demand $\left[\mathrm{kWh} \cdot \mathrm{m}^{-2} \cdot \mathrm{yr}^{-1}\right]$} \\
\hline Type 1 & $\mathrm{B} 3$ & $\mathrm{~B} 4$ & $\mathrm{C} 1$ & $\mathrm{C} 2$ & $\mathrm{C} 3$ & $\mathrm{D} 1$ & $\mathrm{E} 1$ \\
Type 2 & 67.15 & 79.75 & 157.00 & 134.50 & 160.80 & 233.40 & 274.10 \\
Type 3 & 58.80 & 46.30 & 90.10 & 77.40 & 94.30 & 138.15 & 162.15 \\
Type 4 & 40.20 & 27.90 & 67.05 & 53.80 & 67.40 & 104.05 & 122.70 \\
\hline Weighted & 78.30 & 54.90 & 116.40 & 123.10 & 128.60 & 184.00 & 227.40 \\
average & & & & & & & \\
\hline & Heating & demand & covered & by HVAC systems & {$\left[\mathrm{kWh} \cdot \mathrm{m}^{-2} \cdot \mathrm{yr}^{-1}\right]$} \\
\hline Type 1 & 37.90 & 23.16 & 98.13 & 72.63 & 73.16 & 159.88 & 205.58 \\
Type 2 & 25.17 & 15.33 & 66.75 & 49.41 & 49.60 & 110.94 & 143.25 \\
Type 3 & 21.81 & 13.45 & 56.31 & 41.80 & 42.91 & 94.63 & 121.61 \\
Type 4 & 14.91 & 8.10 & 41.91 & 29.05 & 30.67 & 71.27 & 92.03 \\
\hline Weighted & 29.05 & 15.94 & 72.75 & 66.47 & 58.51 & 126.04 & 170.55 \\
average & & & & & & & \\
\hline
\end{tabular}

Heating demand covered by HVAC systems

compared with computed heating energy demand [\% ]

\begin{tabular}{lllllll}
37 & 29 & 63 & 54 & 46 & 69 & 75 \\
\hline
\end{tabular}

Table 7: Computed heating energy demand vs. energy demand actually covered by the installed heating systems per $m^{2}$ and $y r$ for multifamily houses. Split per climatic zone and typology. Period (1940-1980). (Source: Own elaboration). 
In general, as the energy demand calculated was higher than the energy demand covered by the facilities, the actual consumption for heating and cooling is lower than expected by the calculations made according to the law.

\section{Estimation of the consumption and $\mathrm{CO}_{2}$ emissions.}

\subsection{Distribution of the energy consumption.}

The main sources of information used in this section regarding energy consumption were:

1. Aggregated data of actual energy consumption of the residential building stock from the Valencian Energy Agency [14] expressed in tonnes of oil equivalent (toe) and referring to the year 2007.

2. The Census of Population and Dwellings 2001 [7], of the Spanish National Institute of Statistics (INE).

3. 500 surveys carried out by IVE to obtain actual energy consumption data in the Comunitat Valenciana region referenced to climatic zones [16].

4. National statistics [11] regarding the energy consumption of the residential sector and the consumption habits of the citizens.

The information from item 1 was calibrated with the data coming from the other three items by fixing coefficients which adjusted the computed data to the actual energy consumption.

The analysis of the collected information led to:

- The percentages of energy-use per service: heating and cooling, domestic hot water (DHW), cooking and other equipment as lights or appliances.

- The percentages and total consumption per energy type and per service: DHW, cooking and other equipment.

The results are shown in Table 8 and Table 9. There are slight differences between the total consumption for heating and cooling shown in these two tables, since they have been obtained from different sources. Due to the fact that the values differ in $46,450 M W h \cdot y r^{1}$, which represents around a $3 \%$ of the total, the assumptions used were supposed to be valid. In Table 8 , the heating and cooling consumption values were obtained from the percentages of energy-use (30\% of the total) [16], while in Table 9, they were obtained from the difference between the total consumption [14] and the service (DHW, cooking and other equipment) consumption per energy type (see [16]). 


\begin{tabular}{lr}
\hline Type of service & Consumption $M W h \cdot y^{-1}$ \\
\hline Heating and cooling & $1,658,930$ \\
DHW & $1,548,334$ \\
Cooking & 497,679 \\
Appliances \& Lighting & $1,824,823$ \\
\hline Total & $5,529,766$ \\
\hline
\end{tabular}

Table 8: Distribution of energy consumption per type of service in multifamily houses built during the period 1940-1980. Data collected during 2007. (Source [16]).

\begin{tabular}{lr}
\hline Type of energy & Heating + Cooling $M W h \cdot y^{-1}$ \\
\hline Gas-oil & 43,528 \\
Liquified gases & 326,704 \\
Natural gas & 259,989 \\
Electricity & $1,075,159$ \\
\hline Total & $1,705,380$ \\
\hline
\end{tabular}

Table 9: Distribution of energy consumptions classified by energy type, dedicated to heating and cooling in multifamily houses built during the period 1940-1980. Data collected in 2007.(Source [14]). 
6.2. Energy consumption for heating $\&$ cooling and estimation of the $\mathrm{CO}_{2}$ emissions.

As explained in section 5.3, there exists a percentage of the energy demand that is not covered by the actual systems. Therefore, the final consumption for heating and cooling is lower than expected. Other authors have also proved that the indoor temperatures in many residential buildings are kept below the levels usually considered as comfortable. This remark has often been explained according to the concept of energy poverty, which occurs because householders, due to lack of incomes, switch off the heating and cooling systems even though they would be required to keep the comfort. In Spain around 7 million citizens have problems for paying the energy bills and one in three unemployed householders suffer from energy poverty. Spain is the fourth European country with more families unable to keep comfortable temperature levels in their homes. Even more disturbing is the fact that the data analysed show an increase in the energy-vulnerability [17].

The energy demand calculated with CERMA was divided by the seasonal efficiency of the heating systems of each building thus providing the consumption values. The type of building and the climatic zone was taken into account to determine the efficiency of the facilities. The seasonal efficiency of each facility is shown in Table 6.

In order to calculate the average $\mathrm{CO}_{2}$ emissions per dwelling and conditioned square meter, the Spanish official energy conversion factors were used [18]. The following emission factors were used:

(a) Gas-oil, 0.26[TCO $2 / M W h]$

(b) Liquified gas, $0.23\left[\mathrm{TCO}_{2} / \mathrm{MWh}\right]$

(c) Natural gas, $0.20\left[\mathrm{TCO}_{2} / \mathrm{MWh}\right]$

(d) Electricity, $0.27\left[\mathrm{TCO}_{2} / \mathrm{MWh}\right]$

Table 10 shows the average $\mathrm{CO}_{2}$ emissions per air-conditioned square meter.

\section{Evaluation of the savings achieved as result of the improvement measures pro- posed.}

The proposed energy saving measures were devised to meet the Spanish Building Regulation and range from the simplest to the most complex ones. These measures are based on the Construction Characteristics Catalogue [10], but focusing on the thermal comfort and the original cost as the main priorities. The options were arranged into four categories regarding the 


\begin{tabular}{|c|c|c|c|c|c|c|c|c|}
\hline \multirow{2}{*}{ HVAC System } & \multicolumn{8}{|c|}{ Mean $\mathrm{CO}_{2}$ emissions per climatic zone $\left[\mathrm{kgCO} \mathrm{O}_{2} \cdot \mathrm{m}^{-2} \cdot \mathrm{yr}^{-1}\right]$} \\
\hline & B3 & B4 & $\mathrm{C} 1$ & $\mathrm{C} 2$ & C3 & D1 & E1 & Mean \\
\hline Heating & 5.32 & 2.89 & 17.61 & 16.10 & 14.00 & 32.26 & 52.83 & 6.62 \\
\hline Cooling & 0.62 & 1.00 & 0.00 & 0.26 & 0.62 & 0.00 & 0.03 & 0.67 \\
\hline Total & 5.94 & 3.89 & 17.61 & 16.36 & 14.62 & 32.26 & 52,86 & 7.29 \\
\hline
\end{tabular}

Table 10: Mean value of the $\left[\mathrm{kgCO}_{2} \cdot \mathrm{m}^{-2} \cdot \mathrm{yr}^{-1}\right]$ emissions due to heating and cooling for multifamily houses built between 1940-1980 at the Comunitat Valenciana (Spain). The calculations were performed using CERMA as a national tool for the EPDB.(Source: own elaboration). 
refurbishment of the building envelope and particularly focused on increasing its insulating performance. This approach is similar to other European studies (see for instance an Italian case [19]). The classification was set as follows:

(a) $\mathrm{MH}$, improvements in windows.

(b) MQ, improvements in roofs.

(c) MF, improvements in facades.

(d) MX, combinations of the previous improvements.

In order to evaluate the energy saving measures, the original building, named M0, was taken as a benchmark for the current situation. The different packages of energy saving measures [8] were applied to the model in order to establish the energy saving percentages achieved.

Table 11 shows a detailed description of all the proposed measures. The measures in boldface were finally adopted for this study since they turned out to be the most effective.

\subsection{Energy savings achieved depending on the building typology.}

In first place it should be pointed out that the results of the simulation showed that the thermal performance of the archetypical buildings were affected by its geometry (compactness, height, etcetera). The compactness, i.e. the ratio between the volume of a building to the external surface area of its envelope, has a great influence on the thermal performance of the building. Moreover, the ratio of external area of a constructive element to the whole area of the envelope, is the main parameter to assess its energy saving potential.

One of the main conclusions of the current paper is that the improvement of the thermal insulation of the buildings would produce energy savings in a range between a $6 \%$ and $73 \%$ by simply insulting the roof or by insulating the whole envelope, respectively. In general when the whole building is insulated, the savings are always over $50 \%$.

In the case of lower buildings, changing the windows or insulating the roof, resulted in similar savings. However, in high rise buildings, changing windows is more effective than insulating the roof. Regarding the window improvements, type 4 building has the greatest saving potential, as the window area represents a larger area of the total envelope when comparing with other building types. Seemingly, improvements in the roof of type 1 building produce the greatest savings owing to its higher percentage of the external area. The facade insulation of type 2 building has higher energy saving potential due to its compactness.

The analysis of the data obtained from residential building inspections carried out and compiled by the Regional Government, shows that the most common renovations done by the building 


\begin{tabular}{|c|c|c|c|c|}
\hline Code & & \multicolumn{3}{|l|}{ Features of the proposed solution. } \\
\hline M0 & & \multicolumn{3}{|l|}{ Initial building state } \\
\hline $\mathrm{MH}$ & & \multicolumn{3}{|l|}{ Improvements in windows } \\
\hline & MH1 & \multicolumn{3}{|l|}{ replace window glass with double glazed 4-9-6 glass+good fit+weather strip } \\
\hline & MH2 & \multicolumn{3}{|l|}{ replace frame with metallic frame with broken thermal bridge+double glazed 4-9-6+good fit+weather strip. } \\
\hline & MH3 & \multicolumn{3}{|l|}{ double window+metallic frame with broken thermal bridge+double glazed 4-9-6+good fit+weather strip } \\
\hline & MH4 & \multicolumn{3}{|l|}{ double window+metallic frame with broken thermal bridge+double glazed 4-9-6+good fit+weather strip+blind box(airtight and insulated) } \\
\hline MQ & & \multicolumn{3}{|l|}{ Improvements in roofs } \\
\hline & \multirow{4}{*}{ MQ1 } & \multirow{4}{*}{ Roofs insulted to fulfil the $U_{\max }$ and $U_{\text {lim }}$ of the CTE } & $\mathrm{B}$ & $U=0.45\left[W^{-2} K^{-1}\right]$ \\
\hline & & & & $U=0.41\left[W m^{-2} K^{-1}\right]$ \\
\hline & & & & $U=0.38\left[W^{-2} K^{-1}\right]$ \\
\hline & & & $\mathrm{E}$ & $U=0.35\left[W^{-2} \mathrm{~K}^{-1}\right]$ \\
\hline MF & & \multicolumn{3}{|l|}{ Improvements in facades } \\
\hline & MF1 & \multicolumn{3}{|l|}{ Main facade insulated at the internal air gap. Fulfils $U_{\max }$ and $U_{\text {lim }}$ of the CTE. } \\
\hline & MF2 & \multicolumn{3}{|l|}{ Main facade insulated at the internal surface. Fulfils $U_{\max }$ and $U_{\text {lim }}$ of the CTE } \\
\hline & MF3 & \multirow{4}{*}{ Main facade insulated at the internal surface. Fulfils $U_{\max }$ and $U_{\text {lim }}$ of the CTE } & $\mathrm{B}$ & $U=0.82\left[W^{-2} K^{-1}\right]$ \\
\hline & \multirow{8}{*}{$\begin{array}{l}\text { MF4 } \\
\text { MF5 }\end{array}$} & & & $U=0.73\left[\mathrm{Wm}^{-2} \mathrm{~K}^{-1}\right]$ \\
\hline & & & & $U=0.66\left[W^{-2} \mathrm{~K}^{-1}\right]$ \\
\hline & & & $\mathrm{E}$ & $U=0.57\left[W^{-2} \mathrm{~K}^{-1}\right]$ \\
\hline & & Main facade insulated at the external surface. Fulfils $U_{\max }$ and $U_{\text {lim }}$ of the CTE & & \\
\hline & & \multirow{4}{*}{ All facades insulated at the external surface. Fulfils $U_{\max }$ and $U_{\text {lim }}$ of the CTE. Thermal bridges are broken or reduced } & $\mathrm{B}$ & $U=0.82\left[W^{-2} \mathrm{~K}^{-1}\right]$ \\
\hline & & & & $U=0.73\left[W^{-2} \mathrm{~K}^{-1}\right]$ \\
\hline & & & $\mathrm{D}$ & $U=0.66\left[W^{-2} \mathrm{~K}^{-1}\right]$ \\
\hline & & & $\mathrm{E}$ & $U=0.57\left[W^{-2} \mathrm{~K}^{-1}\right]$ \\
\hline MX & & \multicolumn{3}{|l|}{ Different combinations of the previous measures. } \\
\hline \multirow{8}{*}{\multicolumn{2}{|c|}{ MX1 }} & \multirow{4}{*}{ Roof increase insulation until it fulfils $U_{\max }$ and $U_{\text {lim }}$ of the CTE } & $\mathrm{B}$ & $U=0.45\left[W m^{-2} K^{-1}\right]$ \\
\hline & & & & $U=0.41\left[W^{-2} \mathrm{~K}^{-1}\right]$ \\
\hline & & & $\mathrm{D}$ & $U=0.38\left[W^{-2} \mathrm{~K}^{-1}\right]$ \\
\hline & & & $\mathrm{E}$ & $U=0.35\left[W^{-2} \mathrm{~K}^{-1}\right]$ \\
\hline & & \multirow{4}{*}{ All facades insulated at the external surface. Fulfils $U_{\max }$ and $U_{\text {lim }}$ of the CTE. Thermal bridges are broken or reduced } & $\mathrm{B}$ & $U=0.82\left[W^{-2} \mathrm{~K}^{-1}\right]$ \\
\hline & & & $\mathrm{C}$ & $U=0.73\left[W^{-2} \mathrm{~K}^{-1}\right]$ \\
\hline & & & $\mathrm{D}$ & $U=0.66\left[W m^{-2} K^{-1}\right]$ \\
\hline & & & $\mathrm{E}$ & $U=0.57\left[W^{-2} \mathrm{~K}^{-1}\right]$ \\
\hline & MX2 & \multicolumn{3}{|l|}{ Double glazing 4-9-6+frame with broken thermal bridge+good fit+weather strips+blind box(airtight and insulated) } \\
\hline & & \multirow{4}{*}{ Roof increase insulation until it fulfils $U_{\max }$ and $U_{\text {lim }}$ of the CTE } & $\mathrm{B}$ & $U=0.45\left[W m^{-2} K^{-1}\right]$ \\
\hline & & & & $U=0.41\left[W^{-2} K^{-1}\right]$ \\
\hline & & & $\mathrm{D}$ & $U=0.38\left[W^{-2} \mathrm{~K}^{-1}\right]$ \\
\hline & & & $\mathrm{E}$ & $U=0.35\left[W m^{-2} K^{-1}\right]$ \\
\hline & & \multirow{4}{*}{ All facades insulated at the external surface. Fulfils $U_{\max }$ and $U_{\text {lim }}$ of the CTE. Thermal bridges are broken or reduced } & $\mathrm{B}$ & $U=0.82\left[W m^{-2} K^{-1}\right]$ \\
\hline & & & & $U=0.73\left[W^{-2} \mathrm{~K}^{-1}\right]$ \\
\hline & & & & $U=0.66\left[W m^{-2} K^{-1}\right]$ \\
\hline & & & & $U=0.57\left[W^{-2} K^{-1}\right]$ \\
\hline
\end{tabular}

Table 11: Improvement measures.(Source: own elaboration). 
owners are changing windows and insulating the roofs, despite the low savings obtained. The reasons why the owners decide to perform these renovations and not others, is because in the case of windows renovation, they do not have to apply for any permit, and in the case of roofs renovation, this element usually needs repairing works more frequently than other elements.

The simplest energy saving measure which has the highest potential is the improvement of the facade (thermal insulation from outside). It has an impact of about a 27-39\% energy savings.

Regarding the difference between facades insulated from the outside or inside, the first is often more effective. It is possible to get up to a $5 \%$ extra of energy savings.

As the maximum energy demand, allowed by the Spanish regulations (see section 5.1) depends on the climatic zone, the level of insulation should change accordingly. Therefore, the comparison of the results among different climatic zones is meaningless.

\subsection{Investment costs and savings in a typical dwelling.}

Based on the information included in section 5.2 about the four residential buildings types established for Comunitat Valenciana Region, a typical dwelling is defined as a weighted average of these four types, according to their amount within the total building stock.

The selection of the energy saving measure to be implemented depends on: capital availability, financial criteria, and uncertainties in the actual energy savings achieved and future energy costs [20].

On the basis of these criteria, an analysis of the investment costs (public or private) was done for each energy saving measure and climatic zone. It was estimated that a subsidy close to the $50 \%$ of the investment costs would be needed, considering the potential savings and a payback period of 10 years. This $50 \%$ subsidy for each house in the Comunitat Valenciana represents the optimum for each measure and climatic zone. The climatic zones have been grouped as follows:

- hot zones: B3 and B4.

- warm zones: $\mathrm{C} 1, \mathrm{C} 2$ and $\mathrm{C} 3$.

- cold zones: D1 and E1

As an example Figure (1) shows the calculated returns on the investment required to implement measure MX2 in hot zones for the typical dwelling. For the same amount of money invested, two cases are represented. On the left, the case in which the energy consumption of the typical dwelling equals the weighted average of the actual energy consumption (see section 6) of the building stock. The case on the right, represents an upper limiting case: the thermal 


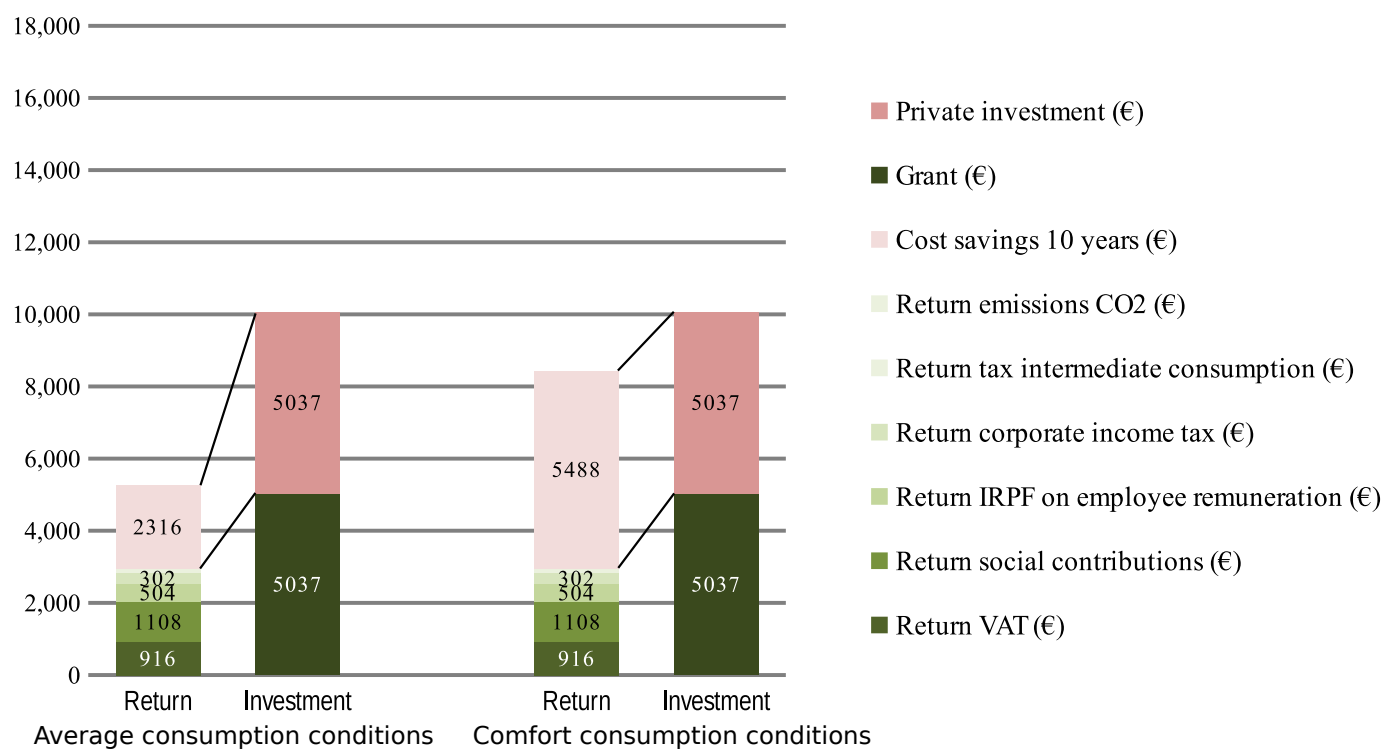

Figure 1: Estimated savings and investment returns for MX2 solution. Remark: IRPF is the Spanish acronym for PIT, Personal Income tax. (Source: own elaboration). 
comfort is theoretically assured according to the Spanish law (see section 5.3) and therefore the estimated initial reference value of the energy consumption is the highest and also the energy saving potential. The economical investment has been differentiated between public and private, in order to identify the expected returns from the public investment.

In general, all the investment paybacks were calculated as the ratio between the private investment (Euros) and the energy savings (Euros/year) of a typical dwelling in the Valencia Region per improvement measure and per climatic zone.

Figure (2) shows the amortization without subsidies using the actual average energy consumptions. The three lines represent payback periods of 10,20 and 50 years respectively of the private investment. They allow to estimate the feasibility of each improvement measure at each climatic zone.

Figure (3) shows the same case of Figure (2) but with a $50 \%$ economical subsidy applied. In this case the three lines move leftwards with respect to Figure (2), because the return period of the private investment was decreased. Finally, higher energy savings are achieved when the requirements established by the Spanish Building Code CTE [15] are enforced (see section 5.3).

As expected, in hot climatic zones is where the payback period becomes longer. Unfortunately, even with $50 \%$ subsidy, the buildings in the hottest zones could not reach payback periods of less than 20 years, which points to strong financing difficulties.

\section{Energy Upgrade scenarios.}

The initial hypotheses developed about trends in energy consumption for HVAC in dwellings until the year 2020 for the Valencia Region are outlined below. These hypotheses provide the base to establish several scenarios of possible improvement measures:

- In the last 10 years, energy consumption in dwellings has risen by around a 50\%. Due to the parallel growth in the building stock during those years a more realistic value of $32 \%$ was assumed.

- A linear increase of the energy consumption for heating of $0.3 \%$ per year was predicted, up to reach at least $40 \%$ of the theoretically estimated demand.

- A linear increase of the energy consumption for cooling of $8 \%$ per year is proposed, up to reach at least $30 \%$ of the theoretically estimated demand. According to the information 


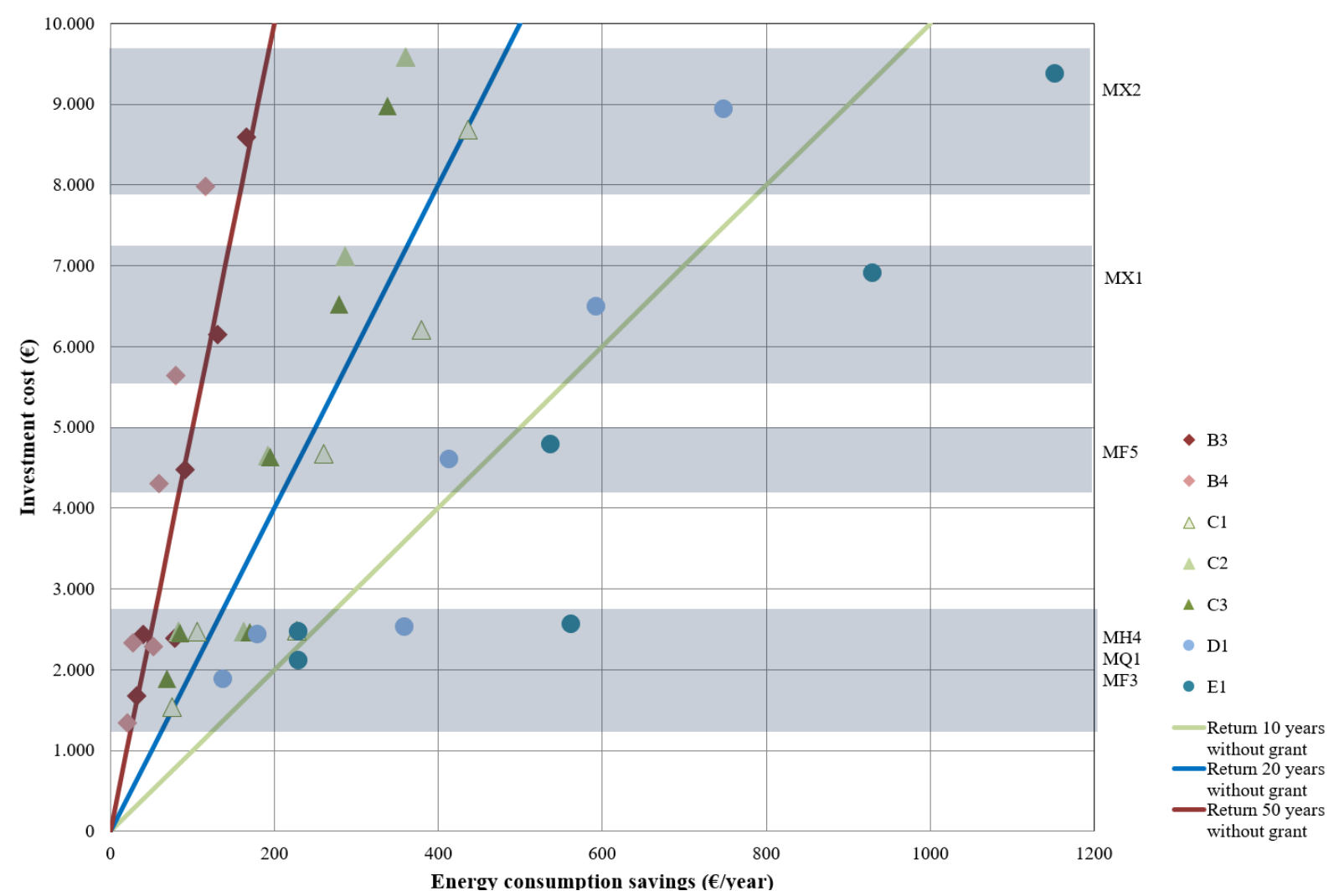

Figure 2: Private investment amortization for a typical dwelling at the Comunitat Valenciana, without subsidy and with a mean energy consumption.(Source: own elaboration). 


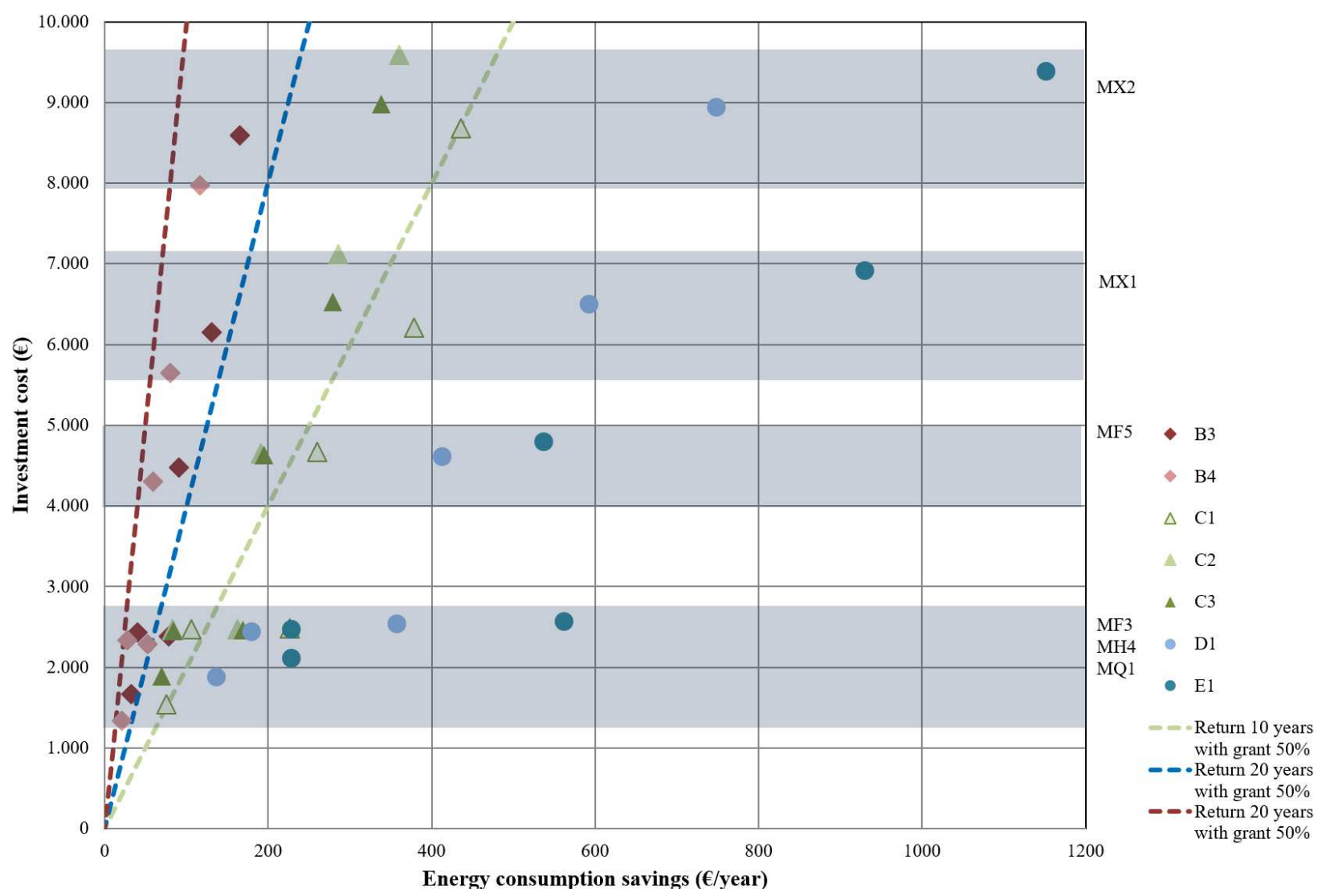

Figure 3: Private investment amortization for a typical dwelling at the Comunitat Valenciana, with 50\% subsidy and with a mean energy consumption.(Source: own elaboration). 
offered by the Applied Thermodynamics Department at the Polytechnic University of Valencia, the average sales of refrigeration or air conditioning equipment are growing at $15 \%$ per annum.

- A reduction in the $\mathrm{CO}_{2}$ emissions associated with energy generation of about $10 \%$ a year is proposed.

- Despite a large body of empirical literature, there is no consensus yet as to the best way to capture the true dynamics of energy price changes. There is a great complexity and some authors [21] defend that the variability of the trend suggests that forecasting energy prices should not typically occur about a single trend. Our study assumed that the price of the energy was going to increase by around 30\% above the inflation rate during 2012-2016 period. In other words a $6 \%$ increase per year during 5 years.

Taking into account the previous hypothesis, the energy consumption was estimated from the base year 2007 until the 2020 horizon. In order to establish the possible scenarios, it was proposed to use the energy saving measures focused on the thermal envelope but taken separately; facades, roofs and windows.

In order to decide the allocation of money it was necessary to weight each strategy by evaluating the energy consumption savings achieved by each respective measure. One outstanding conclusion is that the savings achieved by the facades in the most common typologies (types 1 and 2) almost double those of the windows, and almost triple those of the roofs. In concrete, for type 2 buildings, renovations of the facades may be even five times more effective than those of the roofs. Therefore, the greatest weight is assigned to the facades. Obviously, the smallest weight is given to the roofs. Table 12 shows the proposal where the facade has a $60 \%$ weight ( $30 \%$ from outside $+30 \%$ from inside), windows have $30 \%$ weight and roofs have $10 \%$ weight:

\section{Main results}

Before explaining the results some remarks should be made:

- The results obtained are related to a renovation which affects half of the housing stock, built between 1940 and 1980. The reason is that we focused exclusively on multifamily houses used as main residence as they are the ones having the greatest potential.

- The study has been carried out assuming that a $50 \%$ subsidy may be obtained. This includes: European, National and regional grants. In addition, an evaluation of the financial 


\begin{tabular}{llc}
\hline Constructive element & Measure & Weight (\%) \\
\hline \multirow{2}{*}{ Facades } & MF5: insulate at the external surface & 30 \\
& MF3: insulate at the internal air gap & 30 \\
Roofs & MQ1: insulate at the roof & 10 \\
Windows & MH4: double glazing & 30 \\
\hline
\end{tabular}

Table 12: Relative weight of the improvement measures.(Source: own elaboration). 
measures has been made in order to obtain payback periods of 10 years via taxes like VAT, via direct taxes to individuals or companies related to $\mathrm{CO}_{2}$ emissions; or via social security payments or corporate taxes.

- The implementation budget already includes an assumed industry-norm profit margin, as well as the indirect costs. Construction prices were taken from the IVE construction costs database for the year 2011 [22].

- The final costs of the investment include an implementation budget margin of $10 \%$ to take into account the expenses due to project management and licenses. They also include the corresponding VAT tax.

- Where building owners need private financing (e.g. loans) to be able to invest, the costs of the interest arisings should be added to the total budget. This is predicted to increase of the total budget by an estimated $10 \%$.

- The energy saving measures studied relate exclusively to the buildings envelope; facade, windows and roof, as they are more durable and require less maintenance than HVAC facilities. On the other side it has been proved that, in Valencia Region, when individual home owners own their own HVAC facilities, they usually upgrade their heating and cooling systems on their own initiative. In the Comunitat Valencia the HVAC facilities are rarely shared by several owners living in multifamily buildings. This private ownership of HVAC systems means that they are more likely to be well maintained or indeed replaced with newer units as required. The installations shared by several owners are harder to maintain since the agreement of the majority of the owners is always needed.

Table 13 reflects the results obtained with different yearly rates of renovations in the housing stock.

As a starting point, the regional government had a record of an annual renovation rate of 10,000 homes per year based on the average over the last five years. This includes all kind of interventions, not just energy retrofitting. So, assuming that all future actions will have an energy improvement, with the current trend the savings achieved would not exceed $1 \%$.

Looking at Table 13, scenario E1 equates to an intervention on the $10 \%$ of the housing stock built between 1940-1980, representing around 69,000 dwellings. The energy consumption could be reduced up to $2 \%$ in 10 years. This reduction represents an accumulated saving of 247,871 $[M W h]$ with a total investment of 244 million Euros. 


\begin{tabular}{|c|c|c|c|c|c|c|}
\hline \multirow{2}{*}{ Intervention } & \multicolumn{6}{|c|}{ Possible scenarios } \\
\hline & E1 & E2 & E3 & $\mathrm{E} 4$ & E5 & E6 \\
\hline \multicolumn{7}{|c|}{ Characteristics of the building stock } \\
\hline Percentage of intervention & $10 \%$ & $20 \%$ & $30 \%$ & $40 \%$ & $50 \%$ & $80 \%$ \\
\hline Number rehabilitated dwellings by 2021 & 69,254 & 138,518 & 207,782 & 277,048 & 346,308 & 554,105 \\
\hline Number of yearly rehabilitated dwellings & 6,925 & 13,852 & 20,778 & 27,705 & 34,631 & 55,411 \\
\hline \multicolumn{7}{|l|}{ Savings } \\
\hline Energy savings in a 10 years span & $2 \%$ & $5 \%$ & $7 \%$ & $10 \%$ & $12 \%$ & $20 \%$ \\
\hline Energy consumption saved $[M W h]$ & 247,871 & 495,969 & 744,016 & 992,143 & $1,240,259$ & $1,984,494$ \\
\hline Cuts in fossil $\mathrm{CO}_{2}$ emissions $[\mathrm{T}]$ & 54,804 & 109,660 & 164,504 & 219,367 & 274,227 & 438,782 \\
\hline Money savings 10 years span [MEuros] & 62 & 124 & 186 & 248 & 310 & 495 \\
\hline Money savings 20 years span [MEuros] & 143 & 286 & 429 & 571 & 714 & 1143 \\
\hline Money savings 30 years span [MEuros] & 224 & 448 & 671 & 895 & 1,119 & 1,790 \\
\hline \multicolumn{7}{|l|}{ Costs and subsidies } \\
\hline Execution budget [MEuros] & 201 & 403 & 604 & 806 & 1007 & 1612 \\
\hline Investment costs [MEuros] & 244 & 488 & 731 & 975 & 1219 & 1950 \\
\hline Subsidies costs $50 \%$ [MEuros] & 122 & 244 & 366 & 488 & 609 & 975 \\
\hline Cost private investment [MEuros] & 122 & 244 & 366 & 488 & 609 & 975 \\
\hline Fossil $\mathrm{CO}_{2}$ emissions returns [MEuros] & 1 & 1 & 2 & 2 & 3 & 5 \\
\hline VAT returns [MEuros] & 22 & 44 & 66 & 89 & 111 & 177 \\
\hline Social security payments returns [MEuros] & 27 & 54 & 80 & 107 & 134 & 215 \\
\hline Direct taxes over workers' salary returns [MEuros] & 12 & 24 & 37 & 49 & 61 & 98 \\
\hline Direct taxes over companies' profit returns [MEuros] & 7 & 15 & 22 & 29 & 37 & 59 \\
\hline Tax over intermediate consumptions returns [MEuros] & 2 & 5 & 7 & 10 & 12 & 20 \\
\hline Number of jobs created by the end of 2021 & 5368 & 10736 & 16082 & 21450 & 26818 & 42900 \\
\hline
\end{tabular}

Table 13: Scenarios for the energy renovation of the housing stock built between 1940 and 1980, for a 10-year span, ranging from 2012 to 2021.(Source: own elaboration). 
To reach savings of $10 \%$ an intervention to over the $40 \%$ of the stock would be needed ( scenario E4). This would lead to accumulated savings of 992,143 [MWh] and a total investment of 975 million Euros.

$20 \%$ energy savings are only reached in scenario E6. This requires an intervention on over $80 \%$ of the stock and it would get an energy consumption reduction of 1,984,494 [MWh] and a total investment of 1,950 million Euros and a renovation annual rate of 55,000 dwellings per year. This proposal is quite unfeasible to be performed within 10 years.

Assuming that a subsidy of $50 \%$ could be obtained and taking into account the money savings due to the energy consumption reduction during 10, 20 and 30 years, the situation by 2021 would be that shown in Figure (4).

Figure (4) shows that without subsidies the owners will recover the investment in 30 years approximately. However, with a $50 \%$ subsidy the payback time would be reduced to 18 years. This fact is important because paybacks periods of 10 years are more attractive to ESCOs who could assume the risk of investment. Figure (5) distinguishes between public and private investments and returns using a colour code. The pinkish tones indicate private values while the greenish ones are for public values. It shows the calculated returns on the investment required to each scenario, differentiating between public or private investment.

In general, the public subsidies could be recovered, up to a $60 \%$ of their amount, within 10 years. This takes into account returns from taxes, social security payments and $\mathrm{CO}_{2}$ emissions taxes. In order to estimate the returns, the values from Table 14 were considered.

Finally, with respect to the private investment, even with a subsidy of $50 \%$, it can be observed that the achieved savings during 10 years, will never equal the amount of the investment, in any scenario. It will reach a $70 \%$ of that investment. Almost 18 years would be necessary in order to completely recover the investment.

\section{Conclusions}

The reduction in greenhouse gases required by climate change obligations and the path to carbon neutral communities represent long lasting and urgent challenges for the governments based on the "Roadmap for moving to a competitive low carbon economy in 2050" (EU COM $112 / 2011$ ) with the objective to reduce greenhouse gas emissions by $80-95 \%$ by 2050 in comparison to those of 1990 [23].

Building renovation is also seen as a key component of improving the economic conditions in Spain, by reviving the construction sector and revitalising urban areas [24]. If the target of a 


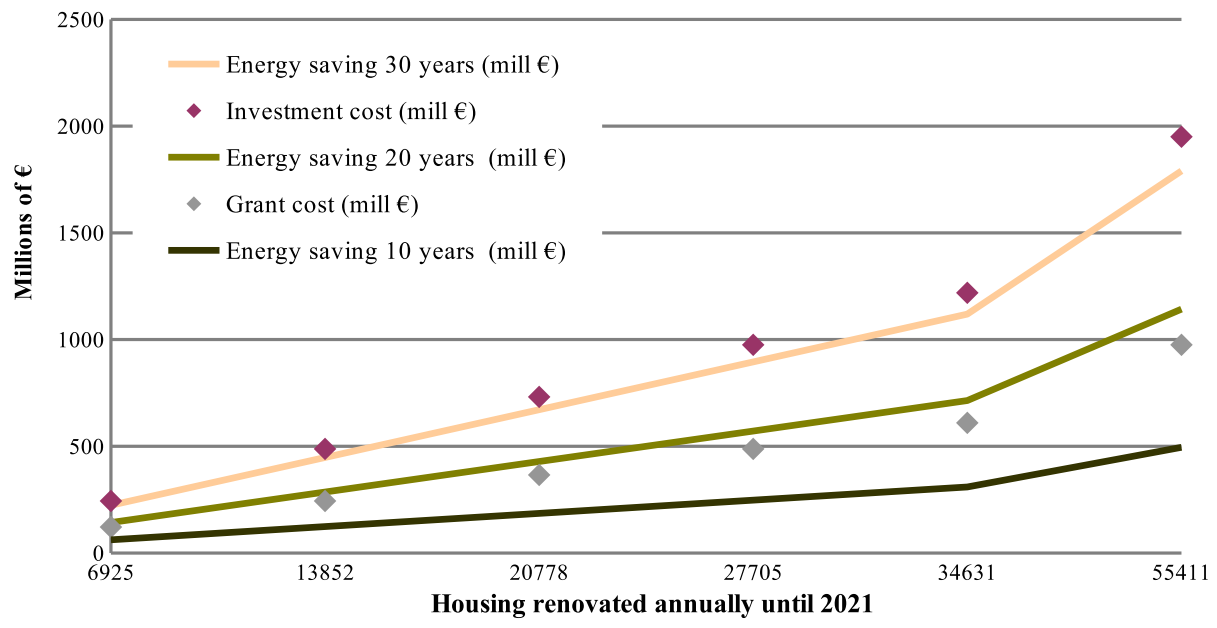

Figure 4: Cost of the private investment by 2021 and possible returns.(Source: own elaboration).

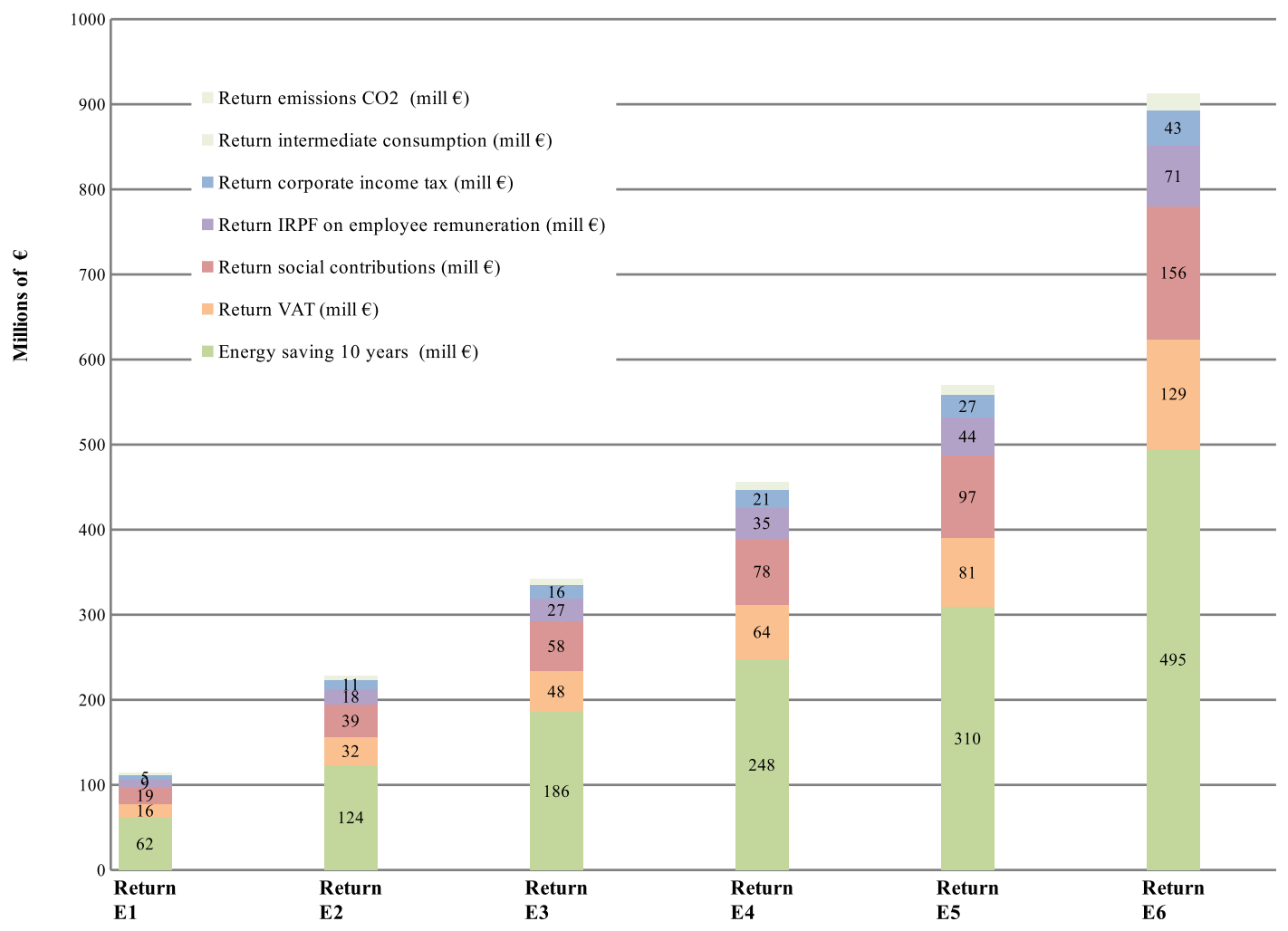

Figure 5: Estimated returns due to savings and taxes by scenarios of actuation. Public subsidy (50\%) plus private investment costs, by 2021, in millions of Euros equals to: E1=244, E2=488, E3=732, E4=976, E5=1218, E6=1950. Remark: IRPF is the Spanish acronym for PIT, Personal Income Tax. (Source: own elaboration). 


\begin{tabular}{rr}
\hline Concept of the returns & \multicolumn{1}{c}{ Criteria } \\
\hline Vossil $C_{2}$ & $11[$ Euros $/ T]$ \\
VAT & $10 \%$ of the tax base \\
Workers' social security payments & $11 \%$ of the investment costs \\
Direct tax over the workers' salary & $5 \%$ of the investment costs \\
Direct tax over the companies & $3 \%$ of the investment costs \\
Tax over intermediate consumptions & $1 \%$ of the investment costs \\
\hline
\end{tabular}

Table 14: Criteria for the possible returns of the public investment. (Source: own elaboration). 
$20 \%$ or higher reduction in the final energy consumption is required by the year 2021, then the percentage of energy retrofitting of the housing stock would have to be at least $80 \%$ (scenario E6). It would mean a renovation rate over 55,000 dwellings a year. This number is much higher than the actual rates and quite unlikely to be reached. The investment needed in scenario E6 is 1,406 million euros. Perhaps a more reasonable scenario would be E4. It assumes a renovation of $40 \%$ of the stock considered in the study. The renovation rate would be 27,000 dwellings per year and the energy savings will be about $10 \%$. In this latter case the estimated investment is 703 million euros. On the other hand, scenario E1, which implies only a $10 \%$ intervention and whose renovation rate is in agreement with the actual rates proposed by the last Housing Plan in the Valencia Region, would produce energy consumption savings of just around 2\%, which are relatively insignificant in the face of the overall Climate Change challenge.

Looking at these results, it should be stressed that the improvement measures proposed in this study were oriented towards the fulfilment of the current legislation [15] and the intervention focuses only on the facades as the savings achieved are demonstrated as the highest. Another option which would deliver similar savings, but reducing the percentage of intervention over the whole stock, would be to go through the modification of the legislation limits by increasing its minimum requirements and approaching the Nearly Zero Energy Buildings concept. In any case the priority should be given to the intervention over the envelope of the building.

Once the highest possible savings are obtained by improving the envelope, then the strategies to improve the HVAC facilities and equipment should be addressed. The possibility of using renewable energy should be studied but the cost would rise compared with non-conventional systems. It is worthwhile recalling that the energy consumption values used must be realistic, taking into account that the outputs from calculation schemes (the National Energy Certification of Buildings scheme), are higher than actual ones. The data used in this study are about the $60 \%$ of those obtained with the energy evaluation tools. As a consequence the resulting savings using the energy certification scheme are much higher and therefore were not used when posing realistic energy upgrade scenarios.

Finally the interventions posed with subsidies of $50 \%$ have been proved to be viable with payback periods of 10 years, while without these grants the payback periods go as high as 25 years or more. 


\section{Acknowledgements}

This research has been supported by the Valencia Government- Conselleria of Housing, Public Works And Territorial Structure, by the research institute Valencia Institute of Building (IVE) and by the Intelligent Energy Europe Programme of the European Union through EPISCOPE project.

\section{References}

[1] EC, Directive 2010/31/eu of the european parliament and of the council of 19 may 2010 on the energy performance of buildings (recast) (2010).

URL http://eur-lex.europa.eu/legal-content/EN/TXT/?uri=CELEX : 32010L0031

[2] W. G. for Rehabilitation GTR, A national perspective on spains buildings sector.a roadmap for a new housing sector., Tech. rep., GBC Spain (2011).

URL http://www.gbce.es/archivos/ckfinderfiles/Investigacion/libro_GTR_engl_postimprenta.pdf

[3] D. P. Team, Collecting data from energy certification to monitor performance indicators for new and existing buildings, Tech. rep., European Research Project (2009).

URL http://www.meteo.noa.gr/datamine/

[4] T. P. Team, Synthesis report sr1: Use of building typologies for energy performance assessment of national building stocks.existent experiences in european countries and common approach ., Tech. rep., European Research Project (2010).

URL http://episcope.eu/fileadmin/tabula/public/docs/report/TABULA_SR1.pdf

[5] L. Radulov, N. Kaloyanov, H. Petran, D2.1 report on the preliminary assessment of public building stock, Tech. rep., European Research Project (2014).

URL http: //www.republiczeb.org/

[6] I. Cerd, Final report rehenergia project, Tech. rep., REHNERGIA PROJECT (2008).

[7] S. N. S. I. (INE), Population and housing censuses, Tech. rep., INE (2001).

URL ine

[8] F. Zhao, S. H. Lee, G. Augenbroe, Reconstructing building stock to replicate energy consumption data, Energy and Buildings (2015) doi:http://dx.doi.org/10.1016/j.enbuild.2015.10.001.

URL http://www.sciencedirect.com/science/article/pii/S0378778815303157 
[9] INE, Population and dwelling data. 2011, Tech. rep., Instituto Nacional de Estadstica (2011).

[10] A. Garcia-Prieto, B. Serrano, L. Ortega, Catalogue for constructive elements for retrofiting, Valencia Institute of Building, 2011.

[11] IDAE (Ed.), Analysis of energy consumption in the residential sector in Spain, Spanish Ministry of Industry and Energy and Tourism, 2011.

URL http://www.idae.es/uploads/documentos/documentos_Informe_SPAHOUSEC_ACC_f68291a3.pdf

[12] J. M. Pinazo, E. Sarabia, V. M. Soto, CERMA. Energy Simulation Software, Spanish Technical Association of Air Conditioning and Refrigeration (ATECYR), Valencia Institute of Building (IVE), Valencia, Spain, spanish technical association of air conditioning and refrigeration (atecyr), valencia institute of building (ive). Edition (2011).

URL http://www .minetur.gob.es/energia/desarrollo/EficienciaEnergetica/CertificacionEnergetic

[13] S. I. for Energy Diversification, S. (IDAE), Conditions of acceptance of alternative procedures, Spanish Ministry of Industry and Energy and Tourism, 2009.

URL http://www.minetur.gob.es/energia/desarrollo/EficienciaEnergetica/CertificacionEnergetic

[14] V. R. E. A. (AVEN), Annual report: Energy data comunitat valenciana, Tech. rep., Generalitat Valenciana (2009).

URL http://www.aven.es/attachments/datos_energeticos_2009.pdf

[15] S. M. of Housing, Royal decree 314/2006, technical building code (cte). energy saving chapter. (2006).

[16] V. I. of Building, Final results:valencia energy housing survey, Tech. rep., Valencia Institute of Building (2012).

[17] A. A. de Ciencias Ambientales, Energy poverty in spain. trend analysis, 2014.

[18] S. I. for Energy Diversification, S. (IDAE), Energy conversion factors primary energy-end energy and co2 emission factors, Tech. rep., Spanish Institute for Energy Diversification and Saving (IDAE) (2009).

[19] V. Belpoliti, G. Bizzarri, A parametric method to assess the energy performance of the social housing stock and simulate suitable retrofit scenarios: An italian case study, Energy and Buildings 96 (2015) 261 - 271. doi:http://dx.doi.org/10.1016/j.enbuild.2015.03.017.

URL http://www.sciencedirect.com/science/article/pii/S0378778815002091 
[20] N. Garrido-Soriano, M. Rosas-Casals, A. Ivancic, M. D. lvarez-del Castillo, Potential energy savings and economic impact of residential buildings under national and regional efficiency scenarios. a catalan case study, Energy and Buildings 49 (2012) 119 - 125 . doi:http://dx.doi.org/10.1016/j.enbuild.2012.01.030.

URL http://www.sciencedirect.com/science/article/pii/S0378778812000473

[21] A. Ghoshray, B. Johnson, Trends in world energy prices, Energy Economics 32 (2010) 11471156.

URL http://opus.bath.ac.uk/21095/

[22] V. I. of Building (IVE), Price database construction elements., Va, 2011.

URL http://www.five.es/basedatos/Visualizador/Base11/index.htm

[23] E. COMISSION, A roadmap for moving to a competitive low carbon economy in 2050, Brussels: Communication from the Commission to the European Parliament, the Council, the European Economic and Social Committee and the Committee of the Regions n112.

[24] B. P. I. E. (BPIE), Renovation strategies of selected EU countries, Buildings Performance Institute Europe (BPIE), 2014.

URL http: //bpie.eu/uploads/lib/document/attachment/86/Renovation_Strategies_EU_BPIE_2014.pdf 